their geographical environment. In the East, they are farmers, and although many are very poor and all suffering from the effects of the economic depression, they differ little in condition from their white agricultural neighbours. In the northern hinterland they are hunters and trappers, and have suffered severely from white competition, and the same applies to some extent to the salmon fishing communities of the North-West coast; but the tribes of the Plains region (Alberta) who lost their livelihood with the extinction of the bison and became farmers and ranchers, have in many instances achieved prosperity in two generations. Finally, it may be added, it is possible for an Indian to become enfranchised on certain conditions, and to cease to rank legally as an Indian.

\section{Statistics of Unemployment}

THE report of the Ministry of Labour for 1936 directs attention to the exceptionally sharp rise in the numbers available for employment, which increased by 270,000 between July 1935 and July 1936, due mainly to a rise in the numbers of persons aged sixteen years resulting from the increased birth-rate in the immediate post-War years. Against this there was a large increase in the numbers in employment, which in December 1936 reached the highest level recorded since comparable statistics have been kept$11,132,000$ as against 10,629,000 in December 1935 . There was also a marked decrease in the numbers unemployed, the number of persons registering as unemployed at employment exchanges in December 1936 being $1,629,000$ as against $1,869,000$ in December 1935. This total includes 69,000 'casuals', 195,000 'temporarily stopped' and 82,000 'juveniles'. Analysis of the age distribution of unemployed men and women indicates that the problem of finding work for those in the older age groups is predominantly one affecting men, and that age proves a handicap to obtaining employment when younger persons are available. Severe unemployment continued in the coal mining industry, but on a lower level than in 1935. The position improved in all the metal trade groups; in the cotton industry, unemployment over the whole year was $15 \cdot 7$ per cent compared with $20 \cdot 9$ per cent in 1935. The position improved in the wool industry but remained severe in the jute industry and in textile finishing. Most other industries showed improvement.

There was a marked increase in the number of persons transferred from the depressed areas compared with previous years, and the proportionate increase in the number of families assisted to re-settle was even more notable. In view of the improved employment position, the whole country was thrown open in instructional centre recruitment, preference in allocation to centres being given to men from areas of heavy and prolonged unemployment. Some expansion in physical training is also reported. Juvenile employment conditions also improved, but there was no indication of a general revival of the apprenticeship system of engaging labour. Shortages of juvenile labour relate particularly to boys and girls in the 14-15 age group, and there was a widespread tendency to raise the starting wage of learners, particularly in unskilled and non-progressive employment. The policy of industrial transference of juveniles was continued in certain areas, as well as arrangements for vocational training and guidance and placing in employment. Reference is also made to progress in the decentralization of the work of the Ministry.

\section{Russian Trans-polar Flight}

THReE Soviet airmen, flying a single-engined 960 h.p. monoplane, "Ant 25", left Moscow on June 18 on a non-stop flight to San Francisco via the North Pole. According to the New York correspondent of The Times, they were compelled by poor visibility to land at Pierson Field, Vancouver Barracks, in the State of Washington, on June 20, when within six hundred miles of their goal. They had been in the air for 63 hours 17 minutes, and are stated to have passed near the Pole at an altitude of 14,000 ft. The three airmen, MM. Byelyakoff, Chkaloff and Baidukoff, have been decorated with the Soviet Order of Merit, and Mr. Roosevelt, in a congratulatory message to the Soviet Ambassador in the United States, referred to the flight as a "historic feat".

\section{Palæolithic Implements from Bombay}

Palfolithro implements from the island of Salsette, north of Bombay, of considerable importance as demonstrating for the first time the presence of a palæolithic culture in this region of India, have been placed on exhibition in the British Museum (Bloomsbury). This series of implements is the result of three years' excavations carried out by Lieut.-Commander Todd in Pleistocene deposits of alternating gravel and clay. The implements are of indurated shale and come from various levels of stratification. They include Lower, Middle and Upper Palæolithic types, which, however, differ considerably from previous palæolithic finds in India. The principal site is a quarry at Khandivli, situated some $100 \mathrm{ft}$. above sea-level near the foothills running up to the moun. tainous interior. Mesolithic implements occur as surface finds and also in the caves of Padan not far away, where they are associated with rock engravings. Diagrams of the geological conditions and photographs of the sites are also exhibited with the implements.

\section{Research on Diseases of Farm Animals}

AN extensive programme of investigation into the cause and prevention of disease in farm animals is being undertaken by the Animal Diseases Research Association at Moredun, near Edinburgh, under the direction of Dr. J. Russell Greig. It has for some time become apparent that the existing laboratories and animal accommodation at Moredun were in. sufficient for the Research Association's rapidly extending work, and Treasury sanction has recently been given to the recommendation of the Agricultural Research Council and the Department of Agriculture 